\title{
Gastric signet ring cell carcinoma
}

\author{
Vitorino Modesto dos Santos ${ }^{1^{*}}$, Laura Campos Modesto ${ }^{2}$ \\ ${ }^{1}$ Department of Internal Medicine, Armed Forces Hospital and Catholic University, Brasília-DF, Brazil \\ ${ }^{2}$ University Center of Brasília-DF, Brazil.
}

\section{To Cite}

Santos V. M, Modesto L. C. Gastric signet ring cell carcinoma. J Gastric Surg 2020; 2(4)

\section{Publication history}

Received: December 3, 2020

Accepted: December 10, 2020

Article in press: December 12, 2020

Published online: December 15, 2020

\section{*Correspondence to}

Prof. Dr. Vitorino Modesto dos Santos, MD, $\mathrm{PhD}$

Armed Forces Hospital

Estrada do Contorno do Bosque s/n, Cruzeiro

Novo

70658-900, Brasília-DF, Brazil.

vitorinomodesto@gmail.com

Telephone: + 55-61 39662103

\section{ABSTRACT}

Zemni I et al. reviewed clinic and pathological characteristics and outcomes of gastric signet ring cell carcinomas (J Gastric Surg 2020; 2(3):71-78) focusing on the major prognostic factors of progression-free survival and overall survival including hypoproteinemia, tumor size, stenosis, advanced stage, and recurrence. Most patients were males under 60 years of age. The data were compared with those of non-signet ring cell gastric carcinomas. There was no significant difference in the 5 years overall survival between the compared groups. The increasing incidence of aggressive tumors in an advanced stage with poor outcome is emphasized and additional comments are about gastric signet ring cell tumors that affected a female and an elderly male.

\section{Key Words:}

Gastric cancer, signet ring cell carcinoma, pathology, prognosis. 
Dear Editor,

We read the article by Zemni et al. reviewing the clinic and pathological characteristics and outcomes of 36 cases of gastric signet ring cell carcinoma (SRCC) in Tunisia. [1] This group was compared to 109 patients with nonsignet ring cell gastric carcinomas. The main prognostic factors of progression-free survival and overall survival in SRCC were hypoproteinemia, large tumor size with stenosis, advanced stage, and recurrence. The tumor sites were cardia $(8.3 \%)$, fundus $(33.3 \%)$, antrum $(52.8 \%)$, and total organ $(30.4 \%)$. The patients had $54.25 \pm 11.49$ years and $75 \%$ were under 60 years; $58.3 \%$ were males. More frequent manifestations were epigastric pain $(94.9 \%)$, weight loss $(86.1 \%)$, anorexia $(80.6 \%)$, asthenia $(77.8 \%)$, vomiting $(41.7 \%)$, and bleeding $(11.1 \%)$. The median postoperative follow up was 35.3 (2-139) months, without significant difference in the 5 years overall survival between the SRCC and the non-SRCC. The authors emphasized the current increasing incidence of this aggressive subtype characterized by advanced stage and worse survival outcome than the non-SRCC.[1]

In this setting, two additional comments seem adequate to enhance awareness of non-specialists working in primary health attention about the gastric malignant tumors. A 40-year-old woman presented headache, dizziness, vomiting, mental confusion, ecchymosis, epistaxis, metrorrhagia, melena, anisocoria, as well as nuchal stiffness.[2] Tomography images of the brain revealed a chronic right parietal subdural hematoma managed by surgical drainage, but the clinical condition evolved to irreversible shock. Autopsy studies detected unsuspected cancer measuring $3.0 \mathrm{~cm}$ at the gastric antrum. There was marantic endocarditis, metastases (lungs, liver, bone marrow, lymph nodes, kidney, pancreas, thyroid, uterus, ovaries, adrenals, and meninges). Worthy of note were disseminated ring signet cells of gastric tumor that caused meningeal vessels leak.[2] The authors highlighted the origin of Trousseau's syndrome in mucin-producing cancer. A 71-year-old man presented fever, dyspnea, hemoptysis enterorrhagia and melena, and had diagnoses of a malignant sigmoid polyp, Saint's triad, and Heyde syndrome.[3] Besides, the endoscopic biopsy of an antral lesion revealed a gastric signet-cell tumor. In the preoperative period, he suddenly died, and the autopsy study was not authorized. The role played by Trousseau's syndrome in the causa mortis was strongly considered; however, the hypothesis of a paraneoplastic thromboembolic event was not confirmed. The authors commented on the concomitance of two cancers with the Saint's triad, which disagrees with the hypothesis of an inverse relationship between these conditions.

The three manuscripts herein briefly mentioned may propitiate more awareness about gastric cancers in special, with an increased interest in the possibility of paraneoplastic phenomena associated with other mucinproducing malignancies. Another concern is related to the decreasing rate of autopsies in the last years, with a consequently increased number of diagnostic pitfalls, under-diagnosis, or misdiagnosis.
Acknowledgements

None

\section{Contributors}

VMDS, LCM conceptualized, drafted, and revised the final version of this letter to the editor.

\section{Funding}

No funding was received for this study.

\section{Competing interests}

No benefits in any form have been received or will be received from a commercial party related directly or indirectly to the subject of this article.

\section{Availability of data and materials}

Further information is available from the corresponding author on reasonable request.

\section{Ethics approval \\ Not applicable.}

\section{Provenance and peer review}

Not commissioned; externally peer reviewed.

\section{Open access}

This is an Open Access article distributed in accordance with the Creative Commons Attribution NonCommercial (CC BY-NC 4.0) license, which permits others to distribute, remix, adapt, build upon this work noncommercially, and license their derivative works on different terms, provided

the original work is properly cited and the use is non-commercial. See: http://creativecommons.org/ licenses/by-nc/4.0/

\section{References}

[1] Zemni I, Mansouri H, Ben Safta I, Ayadi MA, Ben Dhiab T, Chargui $\mathrm{R}$, et al. Resectable gastric signet ring cell carcinoma: clinicopathological characteristics and survival outcomes. Journal of Gastric Surgery. 2020;2:71-8.

[2] dos Santos VM, Rodrigues DB, Castro EC, Saldanha JC, Soares $\mathrm{S}$, Teixeira VP, et al. Widespread hematogenous metastases and Trousseau's syndrome in gastric adenocarcinoma. Rev Hosp Clin Fac Med Sao Paulo. 2001;56:91-6.

[3] Santos VM, Carneiro MV, Soares VVP, Silva SA, Yano VM, Garcia C. An elderly man with gastric cancer, Saint's triad and Heyde's syndrome. Rev Gastroenterol Peru. 2018;38:289-92. 